\title{
“BLOODVISTA" MEASUREMENT OF POSTPARTUM BLOOD LOSS
}

\author{
Elsye Maria Rosa'), Aulia Rahmi' ${ }^{2}$, Asri Hidayatº \\ ${ }^{1)}$ Masters Program in Hospital Management, Universitas Muhammadiyah Yogyakarta \\ ${ }^{2}$ School of Midwifery Bunga Kalimantan, Banjarmasin \\ 3)Universitas Aisyiyah Yogyakarta
}

\begin{abstract}
Background: Mothers always face some blood loss after giving a birth. When the loss is excessive, it is called postpartum hemorrhage (PPH). Severe PPH can lead to poor maternal health and even death, particularly in low- and middle-income countries. The difficulty in accurately determining blood loss drives the researchers to make a method to measure postpartum blood loss. This study aimed to create BloodVista as a method to estimate postpartum blood loss.

Subjects and Method: This was a design research to create a method for measurement of postpartum blood loss, called BloodVista. This study was conducted in Banjarmasin, South Kalimantan. A total of 30 post-partum women and 46 midwives were selected randomly. The dependent variables were amount of blood loss, device storage capacity, midwife productivity, and work quality. The data were analyzed descriptively.

Results: BloodVista was able to store $1,800 \mathrm{ml}$ of postpartum blood. This device was easy to use, safe for skin, and economical. BloodVista could be used to determine the amount of blood loss. This device also increased midwife productivity and work quality, as well as helped improve documentation.

Conclusion: BloodVista can be used to determine the amount of blood loss in postpartum hemorrhage. It increases midwife productivity and work quality, as well as helps improve documentation.
\end{abstract}

Keywords: BloodVista, blood loss, postpartum

Correspondence:

Elsye Maria Rosa. Masters Program in Hospital Management, Universitas Muhammadiyah Yogyakarta, Indonesia. Email: elsye@umy.ac.id. Mobile: +628112699241.

The $6^{\text {th }}$ International Conference on Public Health Best Western Premier Hotel, Solo, Indonesia, October 23-24, 2019 | 145 